\title{
The Profile of Social Entrepreneurs Working for Non-Governmental Organizations
}

\author{
Edita Adomaviciute, Brigita Janiunaite and Edita Stuopyte \\ Kaunas University of Technology \\ Donelaicio 73, LT-44029, Lithuania
}

cross'ref http://dx.doi.org/10.5755/j01.ss.77.3.2766

\begin{abstract}
When searching for possibilities to solve social problems, social entrepreneurs who should implement social mission by not seeking personal wellbeing play a specific role. The essential aim of social entrepreneurship is creation of social value and public profit by attempting to conform to societal needs and problems in the ways, which do not provide profit either for a person or an organization. Social entrepreneurs perform most of their activities at nongovernmental organizations (NGOs). The aim of the article is to answer the following questions: what features are characteristic of a social entrepreneur working for a NGO; what profile of a social entrepreneur working for a NGO is distinguished in real performance; how does the disclosed profile correlate with the theoretical model of a social entrepreneur?
\end{abstract}

Keywords: social entrepreneurship, social entrepreneur, non-governmental organization, social value.

\section{Introduction}

Constant changes and creation of innovations are the inherent basis for the activity of every contemporary effective organization. Changes and innovations are not only technical or technological but also a complex social process, in which 'soft' factors where human potential (individual's creativity, innovation, entrepreneurship) is the most important, play an important role. The article focuses on the phenomenon of individual's entrepreneurship.

An entrepreneur is a seeker for new possibilities that lie not only in business where profit is the most important aim but also in the public sector. Here entrepreneurs solve social problems (Zidonis, 2008). Seeking positive longterm changes, people who understand fundamental problems and have a clear vision how to solve them, are able to form a team and dare to experiment as well as care about social problems' solution more than their personal profit, are necessary (Bornstein and Davis, 2010). The increasing perception that the extent of social problems on a global scale is immense and they cannot be solved only by traditional means stimulates the search of new possibilities, which are taken by social entrepreneurs. They strive to work for society welfare by solving social problems by unconventional, creative, innovative, long-run and effective ways. Social entrepreneurs envisage possibilities where other do not notice them and implement ideas not paying attention to any obstacles.

Seeking social goals and creation of social value are the main peculiarity social entrepreneurship (Peredo and McLean, 2006). As Bornstein (2007) notes, social entrepreneurs advance systemic changes in the society: they change models of people behaviour and their understanding.

Different researchers have examined the phenomenon of social entrepreneurship: Bornstein (2007), Bornstein and Davis (2010), Gilmore, Gallagher and O'Dwyer (2011), Light (2009), Mair and Marti (2006), Noruzi, Westover and Rahimi (2010), Peredo and McLean (2006), Thompson (2002), Weerawardena and Mort (2006), Williams and K'nife (2011). Social entrepreneurship as a process is analysed by Bessant and Tidd, (2011), Shaw and Carter (2007). Social entrepreneurship at non-governmental organizations was analysed by Badelt (1997); Hemingway (2005) studied the values of social entrepreneurs.

Even though researchers pay a lot of attention to the phenomenon of entrepreneurship and social entrepreneurship, there is a lack of research focus on social entrepreneurs working for non-governmental organizations. Why is it particularly important to focus on social entrepreneurs working for NGOs?

Social entrepreneurs perform most of their activities at non-governmental organizations (Bygrave and Zacharakis, 2011). According to Badelt (1997), entrepreneurs often establish new NGOs and there they focus on social changes: identification of new needs in the society and rendering of new services, as well as organization's possibilities to offer new (better) quality of services. At non-governmental organizations the purpose of social entrepreneurship is to formulate innovative, better than previous decisions of social problems (Gilmore, Gallagher and O'Dwyer, 2011); in other words, to create social value. According to Weerawardena and Mort (2006), social entrepreneurship creates conditions for NGOs not only to implement their social mission but also to attain long-term goals. Thus the phenomenon of social entrepreneurship at NGOs has a lot of unanswered question yet, first of all, related to the structure of the competence of a social 
entrepreneur functioning in such organizations, as well as to its difference from entrepreneurs working at business organizations; another important field is the expression of competence components in implementing activities of a social entrepreneur at a $\mathrm{NGO}$, as well as relation of components' expression in evaluating particular social entrepreneurs and so on. The article aims to answer the following questions:

- What are the specific features of social entrepreneurs functioning at non-governmental organizations?

- What profile is characteristic of social entrepreneurs working at non-governmental organizations?

The research aim is to disclose the profile of social entrepreneurs working at NGOs.

The research methods of research literature analysis, individual in-depth interview and descriptive content analysis were employed.

The first part of the article reveals the relationship between the concepts of 'entrepreneurship' and 'social entrepreneurship'. The second part distinguishes the features of social entrepreneurs working at NGOs. The third part provides rationale for the methodology of empirical research, whereas the fourth part of the article reveals the expression of features of social entrepreneurship in the employees of NGOs. Finally, the fifth part presents the profile of social entrepreneurs working at non-governmental organizations.

\section{The relationship of concepts 'entrepreneurship' and 'social entrepreneurship'}

As early as in 1934 Schumpeter, Austrian economist, defined entrepreneurship as a process of creativity and the endeavour for innovations - creation of new business combinations (Zidonis, 2008). These combinations can be as follows:

- creation of new, unknown products or conferment of completely new quality to them;

- creation of new, not tested ways of activity;

- discovery, creation and assimilation of new markets;

- discovery of new provision sources and channels;

- implementation of new business fields and their creation.

Thus, according to Schumpeter, the essence of entrepreneurship is innovation (Jucevicius, 1998); Fillis and Rentschler (2010) define entrepreneurship as a process, during which economic or social value is created by using public and private resources in search for economic, social or cultural changes. Entrepreneurship is a process, by means of which individuals strive to use possibilities, even if at the moment they do not have necessary resources (Jucevicius, 1998, referring to Stevenson, Roberts and Grousbeck, 1989). Phills, Deiglmeier and Miller (2008) point out that entrepreneurs notice new possibilities and directions for activity where other organizations even do not intend to test them. In other words, where others see problems or do not see anything at all, entrepreneurs see potential possibilities (Scarborough, 2011).

If the first conceptions refers to entrepreneurship as establishment of new organizations, now the term of entrepreneurship is much broader and includes generation as well as implementation of original ideas (Kaplan and Warren, 2007). According to Kuvykaite and Alimiene (2006), entrepreneurship is a dynamic process created and managed by an entrepreneur; during it new value is created by using innovations. The impulse for entrepreneurial activity is a unique feature to notice and understand continuous possibilities to create what has not been created earlier (Snitka and Gerdvila, 2001). According to Hisrich, Peters and Shepherd (2010), entrepreneurship is behaviour with the following characteristics: initiative, innovative attraction of resources, risk and uncertainty tolerance. It is a dynamic process of economic or social welfare creation. This is a process during which, having made enough efforts and time, as well as having evaluated financial, psychological and social risk, value added is created; money is received and personal satisfaction with achieved results is felt. Entrepreneurship is characteristic not only of the business world - it is an ability of any individual or organization to act proactively and flexibly react to challenges of changing environment in searching for innovative decisions (Pagirys, 2009). Entrepreneurship means the aim and ability to notice and seize possibilities. Often people become entrepreneurs only because they are not satisfied with the present state.

Fillis and Rentschler (2010) distinguish the following three essential dimensions of entrepreneurship: innovation, risk assumption and proactivity. Innovation is the manner of entrepreneurs' activity: they constantly search for new possibilities and ideas to transform them into profitable, valuable and innovative ones. Risk assumption is related both to implementation of innovations within an organization or society and to finding resources and their management. Proactivity relates to entrepreneur's tenacity, ability to adjust to changing conditions and breaking the established norms.

As Snitka and Gerdvila (2001) note, entrepreneurship is the ability to create 'something' practically out of 'nothing'. It is the ability to feel the possibility where others see only chaos, contradictions and confusion. It is the ability to form a team which is a supplement of entrepreneur's abilities and talents. It is the knowledge how to find and manage resources (often borrowed from others), as well as the ability to obtain money when it is necessary. It is readiness to take risks - both personal and financial - as well as to do everything possible in order to attain one's own goals. It is the ability of an individual and organization to be proactive and flexibly react to challenges of the changing environment in searching for innovative decisions (Pagirys, 2009).

Thus entrepreneurship is the process, during which an entrepreneur having recognized the possibility that had not been noticed by others, having properly evaluated and having taken all possible risk as well as having used the available resources creates value. Entrepreneurship combines individual creativity, innovativeness and proactivity.

However, the concept of entrepreneurship goes beyond the business sector (Badelt, 1997). Even though business entrepreneurship is often named traditional entrepreneurship, entrepreneurs act in different spheres of 
society activity: both in educational system and medicine, law, architecture, and social work (Greblikaite, 2011). Entrepreneurship, which manifests in social sphere, is called social entrepreneurship. Social entrepreneurs most frequently function in non-profit organizations. However, as Bygrave and Zacharakis (2011) point out, if entrepreneurs are in principle motivated to create social value, it does not matter in what organization they work: they will be referred to as social entrepreneurs.

Social entrepreneurship, as well as business entrepreneurship, seeks new possibilities to solve problems and creates new approaches to old decisions. The main specific features of social entrepreneurship is revealed in the analysis of activity aims (Williams and K'nife, 2011). The aim of social entrepreneurship is creation of social value, and economic value becomes a by-product contributing in ideas' implementation (Mair and Marti, 2006). In other words, the main motive of this activity is not striving for profit but the wish to solve societal problems. Thus reference is made to social entrepreneurship because it takes place in the social sphere. As Phills, Deiglmeier and Miller (2008) point out, the main stimulus of business entrepreneur's activity is money, whereas social entrepreneurs act according to altruistic motives. They willingly undertake the social mission by not pursuing personal welfare (Bygrave and Zacharakis, 2011). Mair and Marti (2006) define social entrepreneurship as expression of altruism.

Social entrepreneurship, according to Bornstein and Davis (2010), is the process, during which organizations are established or transformed in order to effectively solve social problems. Business entrepreneurs develop competence of public entrepreneurship and perform the o- called creative destruction; social entrepreneurs enable social changes by creating new possibilities how to solve the problems relevant for society by using human and financial resources. In other words, social entrepreneurs create social value by searching for new possibilities. According to Light (2009), social entrepreneurs not only undertake problem-solution of the society but also hope to eliminate these problems on the whole. They are creative destructors changing the society. Referring to Noruzi, Westover and Rahimi (2010), social entrepreneurs should not always be individuals; they can represent small groups, teams, organizations and even communities in order to implement important social changes.

Social entrepreneurship is an organized and systemic performance different from benevolent but not organized attempts (Bessant and Tidd, 2011). It is not only the usual wish to help doomed people but also the possession of the aim to attain efficient and long-term changes. This is the process, during which a new and original way to solve a social problem, which is much more effective, productive, long-run and much stronger than the existing solutions and creates not economic value for a private person but also social value for society (Phills, Deiglmeier and Miller, 2008). Social entrepreneurs are social innovators who create efficient ideas how to improve people life and implement these ideas in cities, countries and sometimes round the world. They are the people who do not accept a negative answer (Bornstein, 2007). It is important to note that social entrepreneurs not only solve problems but also create workplaces for themselves and others, consolidate people to communities, and create a more human environment.

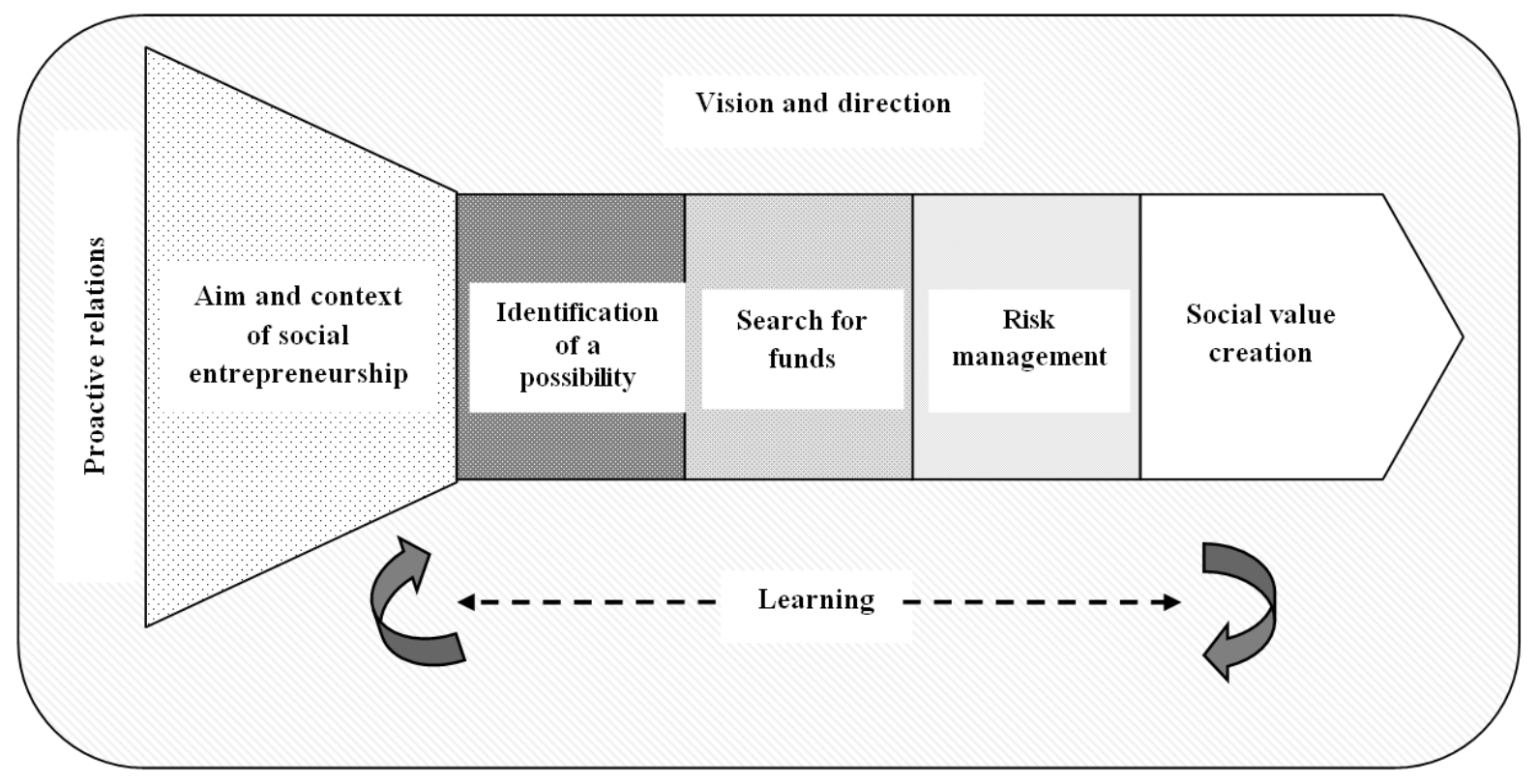

Figure 1. The model of social entrepreneurship process (according to Bessant and Tidd, 2011) 
According to Williams and K'nife (2011), the aim of social entrepreneurship is social progress of the society. Phills, Deiglmeier and Miller (2008) consider the creation of social value an essential aim of social entrepreneurship. Social entrepreneurs seek to solve social problems by invoking business principles and innovative approach to the mission to render society welfare services. They create or apply management and business models in order to achieve social goals (Bygrave and Zacharakis, 2011; Bornstein, 2007). Social entrepreneurship is the value meant for creating social changes. Thus it may be noted that the essential motive of social entrepreneurship is public benefit. As Borstein (2007) points out, social entrepreneurs advance systemic changes in the society: they change models of people behaviour and their understanding. Social entrepreneurs seek their goal by overcoming any resistance until their personal vision becomes a social norm.

When analysing the notion and constituent elements of social entrepreneurship, as well as aims of activity, the concept of social value as the aim of social entrepreneurship or its final result dominates. Business entrepreneurs seek economic value, whereas social entrepreneurs focus on the creation of social value. Social value, as Auerswald (2009) notes, can be defined as a new solution of a social problem, which is more effective and more sustainable than already existing solutions and it is more directed to the needs of the society than of a private person. This is creation of public benefit by responding the society's needs and problems in such ways, which do not ensure benefit either for a person or an organization. Social entrepreneurs can create social value by influencing country's government as well (for example, by initiating enactment of laws) (Auerswald, 2009).

Entrepreneurship and social entrepreneurship are processes (Bornstein and Davis, 2010; Phills, Deiglmeier and Miller, 2008). Every social innovation is not only an instantaneous 'ignition'; it is the entire process that converts ideas into reality. Bessant and Tidd (2011) present the model of innovation and social entrepreneurship (Figure 1), i.e. the process, which has to be organized and managed.

Thus social entrepreneurship process involves:

- the aim, which social entrepreneurs set when they notice social problems;

- environment, which relates a social problem with a particular context or situation, is important in the formulation of aim and further activity;

- vision, which an entrepreneur clearly sees and works for its implementation purposefully;

- identification of a possibility, which is deliberate as well as expedient or unplanned and spontaneous;

- search for finances necessary to implement transformations;

- creation of proactive relations necessary for finance search alongside with potential investors and sponsors; as well as those that determine internationality, collaboration, dissemination of good experience;

- learning - as possibility to implement innovations and changes;
- risk and its management - its estimation, minimization, elimination;

- a process result - the created a social value and/or a successfully functioning socially entrepreneurshiplike organization.

For any process, including social entrepreneurship, to take place, a person or group of persons performing it should possess certain features in order to attain a desired result - that is a social value should be created. Thus further on the article will disclose the essential features of a social entrepreneur are being disclosed.

\section{Specific features of social entrepreneurs}

Social entrepreneurs identify social problems and apply principles of traditional entrepreneurship: to organize, create and control risk in order to ensure social changes (Jucevicius, 1998). Not only the principles of business entrepreneurship are characteristic to social entrepreneurship, but also features of social entrepreneurs mostly coincide with features of business entrepreneurs (Shaw and Carter, 2007). However, considering the specificity of the problems solved, it is possible to recognize several certain peculiar features characteristic only for social entrepreneurs.

Social entrepreneurs, as well as business entrepreneurs, should have a positive attitude towards uncertainty, personal responsibility; they are subject to an action. However, according to Bornstein and Davis (2010), they are not necessarily very charismatic or self-confident. Their success is more determined by their learned life style than inherent features; some people are even born with more tendencies for entrepreneurship. Drucker states that most people can learn to be entrepreneurs (Bornstein and Davis, 2010). Many social entrepreneurs organized their activities in their childhood encouraged by their parents or teachers initiated and organized different activities; their achievements taught them to seek implementation of their ideas.

Social entrepreneurs are perfect listeners (Bornstein and Davis, 2010). They do not have a preconceived attitude, they are tolerant.

Referring to the research performed by Shaw and Carter (2007), great need for achievements and autonomy are more characteristic for business entrepreneurs than social entrepreneurs. Social entrepreneurs are mostly motivated by social aims. Thus the recognition of gaps in social service rendering or satisfaction of social needs is the backbone in motivating them to create and develop their activity.

Differences can be identified by comparing traditional and social entrepreneur in the aspect of taking risk (Shaw, Carter, 2007). In establishing a business organization, all personal or even family financial resources are often used. Social entrepreneurs seldom possess and use personal finances, most frequently they have the disposition of the money obtained from different funds or projects and run the risk with them; thus it is possible to state that they take less personal risk.

Social entrepreneurs must remain strong in order that they would defend their beliefs against sceptics and critics. 
This feature can also have negative outcomes for the entrepreneur; on the one hand, this gives the possibility to ignore those who contradict their ideas; on the other hand, it can determine the disregard of own drawbacks or needs (Bornstein and Davis, 2010). Some social entrepreneurs devote themselves to their work and their ideas that they never marry (though earlier they dreamt about it). They so soak themselves in a subject that they face difficulties in communicating with people, who treat their work only as the part of their life but not as the sense of the entire life. However, social entrepreneurs are certain that they fully realize themselves and such life style gives them satisfaction. Thus social entrepreneurship can also be longterm commitment with a lot of obstacles and frustrations.

According to Mair and Marti (2006), exceptional features are characteristic of social entrepreneurs. They possess leadership abilities, passion to implement their vision and strong moral strength. In contrast from business entrepreneurs, social entrepreneurs do not seek to create welfare for themselves or the organization in which they work. By using their exceptional abilities as well as implementing innovations, social entrepreneurs seek changes wishing to change the world (Bessant and Tidd, 2011). According to Hemingway (2005), social entrepreneurs pursue for constant changes. The aims, for which they pursue, give them the sense of self-esteem and this is much greater value than money for a social entrepreneur.

According to Bornstein and Davis (2010), social entrepreneurs distinguish not only in unusual creativity but also in great responsibility. When solving social problems, they follow not only their intuition - social entrepreneurs consider the decisions being made seriously and responsibly, constantly thinking about possible outcomes (Light, 2009). They are persistent, optimistic, dedicated for their purpose personalities. Although small changes are meaningful, social entrepreneurs orient to great changes. Social entrepreneurs are completely devoted for their vision and persistently pursue their purpose 'to thoroughly change community, society or the world' (p. 48). As Phills, Deiglmeier and Miller (2008) note, the following features are characteristic of a social entrepreneur: courage, responsibility, ingenuity, obstinacy, tenacity in pursuing for the settled aim. According to Badelt (1997), social entrepreneurs are proud of their creativity, are selfconfident and believe in what they do.

Social entrepreneurs initiate social changes. As Light (2009) notes, social entrepreneurs succeed to act individually; however, the best results are achieved when working in a team. Thus they form teams and coordinate their attempts to solve problems much more successfully than therefore. On the other hand, an entrepreneur does not face a problem - almost only possibilities. In problems an entrepreneur sees a possibility to create something new, to do something better. The features different from those of business entrepreneurs are characteristic of social entrepreneurs: responsiveness, empathy and calmness, restraint and insolence, tirelessness and patience to handle the process of changes in spite of indifference, habits, fairs, restriction of resources, lost interest or institutional obstacles. When speaking about restraint, according to
Thompson (2002), most social entrepreneurs even do not consider themselves entrepreneurs and do not tend to speak about their work.

Social entrepreneurs always act according to their competence; they pay the greatest attention and resources to what they still do not know and assess themselves not according to past standards but according to the future vision (Jucevicius, 1998). This induces their constant learning. Altogether entrepreneurs seldom are satisfied with the attained result (unless for a short time) because they already think about future and other possibilities, but not about what has been achieved.

Social entrepreneurs also help others to envisage and evaluate new possibilities. However, these people cannot work when they are not personally interested in the change, when an organization does not give the possibility to experiment and is afraid of possible failure. Social entrepreneurs always are focused on long-term goals (Bornstein and Davis, 2010).

Thus not only essential features of a business entrepreneur are characteristic for a social entrepreneur; social entrepreneurs are distinguished by exceptional features related to the social field they have chosen. The empirical research has allowed finding out how these features disclose in the real activity of social entrepreneurs - employees of NGOs providing social services, as well as how the distinguished profile of a social entrepreneur correlates with the theoretical model.

\section{Research method}

In order to disclose the profile of social entrepreneurs working for NGOs, a qualitative research based on phenomenological research strategy was carried out. The research method was an individual in-depth interview. Three demographic and six open questions of the deep interview were formulated for the interview purposes:

1. What is your age?

2. What is your education?

3. What is your work experience?

4. Why did you decide (or what did you inspire) to work for a NGO which provides social services? (Or to establish it if you are a founder)?

5. What are the aims of your professional activity (how these aims were set, how are they in line with your personal life)?

6. What a NGO should be like to inspire its employees to make social initiatives?

7. What personality features, abilities and knowledge are necessary for a person working for a NGO which provides social services?

8. What was the most successful project/initiative you have implemented (How did the idea emerge? How did you search for resources/sponsors? Are you afraid to take risks? What was the reaction of the society? What are the results of the project/initiative?)

9. What are your future plans?

When performing the analysis of the data obtained during the research, first of all, the informants were described by analysing the information they presented by avoiding interpretation or explanation. The data for the 
analysis were obtained after having transcribed the indepth interviews. Then descriptive content analysis was employed for the analysis of the obtained data.

At first the research sample was formed by applying the method of criterion sample - two informants, who met the requirements of the criteria relevant for the research, were chosen. Considering that the people - those to whom social entrepreneurship is everyday life - can provide the best information about the phenomenon being researched (Groenewald, 2004); the following criteria of informants' selection were distinguished:

- the founder of the NGO that renders social services and functions successfully;

- the author and implementer of the social project/initiative that was successfully implemented (compulsory an employee of a NGO).

The third research participant was chosen according to the method of snowball sample selection from possible informants suggested by the research participants. Considering the ability of a social entrepreneur to widely declare their initiatives, but not a personality; these ways of the sample selection allowed finding interesting and informative cases for the research.

The research process: the interview lasted for 73 minutes on average (the longest -1 hour 50 minutes, the shortest -45 minutes). The interview was recorded and then transcribed. The initial questions of the interview were itemized during every interview when new relevant aspects for the research were expressed or when pursuing to present them the informant much clearer. As the interview was in-depth, no strict succession of the questions was kept; they were asked according to the situation and informant's experience and narrative. During the research all essential principles of the research ethics were kept.

\section{Presentation of the interview participants}

Informant No. 1: 44 year old woman, a citizen of Kaunas, in 2006 she established the association, which renders social services, contributes to diminishing of social exclusion, pursues for social justice. The services rendered by the association aim to strengthen the cohesion of a family and school. The association's activity is based on openness to new ideas, initiatives and experience, responsibility and good-natured work. The association's members often perform the role of intermediaries between a person and the authorities, provide mobile services.

The informant started her social activity from her inner changes. Having found the inner balance, she felt a wish to help other people. Having declined the profitable family business, she has undertaken voluntary activity. She formed a group of amiable colleagues, who also wished to help other people to overcome their problems, and established the association, which consists of 13 members at present. According to the informant, she has always known that she will never be an employed worker and will create workplaces not only for herself but also for other people. The informant was a victim of sneering in her childhood. She has observed the same problems at present school as well. She felt a wish to proclaim these problems in public because she faced indifference and 'extinction' of problems in school community. This induced getting deeper to education policy, aims, and family priorities. The informant's activity is aimed to do well for others, 'divide herself', and stop injustice as well as to right a weaker and crocked person. According to her, it is not enough to support a person financially, it is important to support $\mathrm{him} /$ her morally, to help to develop necessary skills. She particularly values relations - the association collaborates with other organizations, creates the social network both from individuals and legal persons. The respondent thinks that new ideas, problem solution are sent to her by the unseen. She gets positive energy out of her activity; this induces to be more active. Her family's altruistic traditions are characteristic for previous generations as well. The respondent states that it is simple enough to find sponsors and so to raise finances necessary for their activities because potential sponsors notice her enthusiasm.

Informant No. 2: 42 year old man, residing in Vilnius; at present he works for the Charity and Support Fund, the goal of which is to help feed needy people of Lithuania, diminish waste of food, encourage society solidarity and public spirit. He is one of the scholars of the international social entrepreneur network 'Ashoka'. The respondent contributed his ideas and activity to the origins of most NGO, but he does not want claim for them. According to the informant, most ideas 'flutter in the air', only it is necessary to be able to notice them on time but to have enough wish, time, finances and other resources to implement them. He particularly pays great attention to teamwork and corporate performance result; thus he does not want to claim certain initiative, activity or organization alone. The informant assumes that it is unnecessary that social initiative, project or organization would have clearly named its former - it will not give any value added and will not improve the created idea.

Informant No. 3: 42 year old man, residing in Kaunas. $\mathrm{He}$ is one of the founders and leaders of the forum, which the member of the European Parent Association. The organization endeavours to consolidate parents (fosterparents) of Lithuanian children and students for joint activities, which would influence education policy of the country, raise society awareness in the aspect of education system humanization. The organization also renders social services: represents the interests of children and young people, defends their rights in all education and science institutions.

The informant has begun to work in social field because he cannot see injustice: 'naturally, from my inside because I cannot another way'. The informant's activity is based on volunteering principle: he constantly searches for ideas, possibilities; having identified a problem and envisaged its possible solution ways, he informs his colleagues and together with them initiates the changes. As not all ideas gain acceptance, he alone performs some of them, the others are put apart for a later time. One of his basic activity goals - is happy children. The informant has chosen education field because he believes that the children being properly well-bred and educated children will create harmonious families, will raise public-spirited children. Thus to properly educate the younger generation 
is the most important objective. He particularly emphasises the parity - relations between a pupil and teacher must be equal - because they have to learn from one another, not only a pupil from his/her teacher. According to him, harmony must prevail in school community, only then a creative process will take place. In his activity he invokes publicity, media. He acts carefully but decisively. His attitudes are as follows: you should not do anything for a person what you would like to be done for you; it is important to treat people the way they are; everybody is both a pupil and teacher; it is necessary to learn from every situation; it is not advisable to escape difficulties but to solve them; 'in the fight there are no winners'; thus it is necessary to find integrated inter-agreement. He points out that it should not be pursued for very narrow, short-term goals. The informant is not afraid to take a risk, he even does not think about it because he sure of what he does.

\section{The expression of social entrepreneurship features of non-governmental organizations' employees}

When analysing the features of social entrepreneurs employees of the NGO rendering social services distinguished by the informants, it becomes evident that the informants have disclosed all features distinguished in the analysis of scientific literature: the informants express creativity by generating ideas. This is proved by their statements: '... you create, you make something original...', '... there are a lot of ideas...', '... till you are alive you have plans and projects for years...', '... I even got an idea the day before yesterday... '; the respondents overtaking ideas from others state the same: '... you are interested what is going on in the world and having found something interesting you try to adapt it in your environment...'. It is possible to state that the second participant of the research predominantly discloses creativity (both generation of ideas and their interception). The pro-activity of the informants manifests through their personal activity: ('... I am often asked how I manage to do so much...', '...I still have many roles...', '... you should not postpone any role for future...', '... now we have started to actively ... develop ...'), the search of active partners ('...but I see more active people...'). It is important to note that the pro-activity as feature was mentioned by all participants of the research; thus it is really important in the NGO activity. Another feature revealed by the participants of the research - is selfconfidence. It is proved by the statement of the third informant illustrating successful activity: '...We contemplate how we could achieve, by what means... you go and try... - you carefully go, you have already come, next time you feel more courage, already another person follows you...', which reveals not only confidence in new untried activities but also giving the possibility of successful activity for others. The implementation of visions also proves self-confidence: '... it is possible to make great miracles...'. The first informant demonstrates particular self-confidence as personal resolution and courage: '... I really courageously stand against injustice, untruth...', '... I am a very courageous person...', '... I even go where the attitudes are the greatest and I have to experience myself, to see myself...'. By means of preconception avoidance the first and third research participants revealed tolerance as important feature of a social entrepreneur and employee of a NGO rendering social services: '... I do not follow preconceived attitudes and rumours about all those theories...' as well as recognition of person's versatility: '... take another person as he/she is...', '... well, you have to take him/her the way he/she thinks, you cannot teach him/her...', '... I do not condemn people...'. When analysing the expression of another feature important for social entrepreneurs restraint, it is noticed that it discloses in not taking merits for performed activities. This is especially evident in the statements of the second informant: '... but to appropriate, to tell that it is of my organization... no...', '... what for it is necessary, what it will give that you will put a label for yourself or someone that I was the first to create or make something... and you do net get any ... value added and this does not make that created thing better - less labels, just consider how it is...', as well as the first informant thinks that '... those ideas are sent by the unseen, I do not take laurels for myself...'. The restraint of the first and second research participants manifests in their modesty: '... to tell this [organization] is yours it would somehow be indecent for me...', '... do a good job and tell nobody...'. Thus, according to these informants, it is absolutely not important who gets the honour for performed social activities; the most important thing is that they would be carried out. When analysing the informants' answers that reveal moral strength of the employees of the NGOs rendering social services, it becomes evident that it manifests through determination and optimistic thoughts. The statements confirming the determination are as follows: '... really to stand a lot and face the fire...', '... I even go where attitudes are the greatest and I have to experience it myself, to see it myself...'; they express the optimistic thoughts: '... nerves, they had been, but here everything gives benefit, we train our spiritual muscles...'. It is possible to note that the first informant has revealed her moral strength. No doubt that all informants emphasize empathy. It manifests in responsiveness to feelings of another person, in this case of a child ('...I care how another child feels as well...', '... well, so how does that child feel?... '), in sensibility of other person's problems ('... sensibility, that devotion exist...').

The informants have highlighted the essential abilities of a social entrepreneur being distinguished in scientific literature. When analysing the ability to envisage possibilities where others do not see them, the research has proved that the informants disclose it through idea transformation '... well, once I went there, $m$ it seemed it was possible to copy, transfer some idea successfully...', '... you are interested in what happens in the world and having found something interesting you try to adjust it in your environment...', through sharing ideas '... for example here - you have heard, brought, told somebody, somebody has heard, it has become interesting, and it has been developed...', through identification of possibilities in their activity '...we got a clear view what was necessary from that first project...', '... and in the activity I do not know, it very differently, during the night good ideas 
come...', '... a lot of ideas are so paradigm like - they flutter in the air...'. Thus the research participants envisage the possibilities in the experience of other countries and their own everyday activity. They share their ideas with colleagues. The exclusive ability of social entrepreneurs is to innovatively act; also, having performed the research, it has been disclosed in the informants' answers. It manifests through creation of innovations '... they will search for something new...', '... while you always have plans and projects...'; through innovation adaptation '... you are interested what is going on in the world, and, having found something interesting, you try to apply it in your environment. Well, that innovation gets its way..., through innovative ideas '... I told my colleagues that this our project would break the ice...'. Thus the ability to innovatively act has been revealed by all informants and it manifests through the creation of innovative ideas as well as through the adaptation of the initiatives overtaken from other countries. When analysing the very important ability for a social entrepreneur - the ability to initiate social changes, the research has shown that the informants are influenced by the context ('... in the favourable moment when you have enough wish and time and abilities, in that field to do something...', '... I sometimes take is as some environment to which I got and in which I find myself, and the way I can handle it, influence it, I try to influence it ...'), by personal maturity ('... if they are mature enough to understand environment, so you can help the environment, but if you do not understand the environment, you can wish to but not to be able to help...'). The change sustainability is important for the research participants ('Those changes, which have already emerged, cannot be stopped; the aim is that it would develop for the entire school.'), they see change initiation as their goal ('... our goal is to start processes...'). Thus the informants are able to initiate social changes and care for their lasting. The ability to take the risk is disclosed by the belief in own activity and taking responsibility. The statements that prove the belief in own activity is as follows: '... We even did not put such question. Perhaps we were sure enough in what we were doing.', great responsibility: '... in this social field mistakes can be painful...', '... it seems you do not have the right to make a mistake, you have to do everything very well...', '... you must be more careful with the risk in social entrepreneurship than in business... '. However, the ability to figure out and evaluate possible risk has not been identified by the informants. Another very important ability of social entrepreneurs is to raise necessary resources. The research informants have revealed that they raise the resources by invoking the confidence of supporters (the first informant): '... there are the supporters who say that you should do everything, and we will finance you...', '...one sponsor, who can only financially help, comes and he / she says: I believe in you, I have observed you...', '... I see the fire in your eyes, your enthusiasm and the sponsors emerge...', '... they should not be hunted or searched for, they emerge from the environments...'), they themselves search for sponsors (the second informant): '... you yourself start look around, check information, simply inquire, ferret about, and they come...' as well as supporting social initiatives by their finances (the third informant): '... we are all support...', '... we spend our time, fuel, club together for tea...'. Thus the research participants are really able to get financing for the social activities being performed, but they do this by different methods. The research participants have disclosed two more abilities of social entrepreneurs - NGOs employees that are not distinguished in scientific literature. One of them is time management, - according to the first informant, in order to perform a lot of activities in time, it is important to be able to effectively manage your time: '... if you are a specialist of your time and plan everything, you can share yourself...', '... time management is very important... '. During the research all informants have disclosed the ability of their organizations' development. The research participants demonstrate it by establishing organizations: '... we have established the association...', '... it will be the centre of value development, from small to large... ', '... I have contributed to the origins of several organizations...', '... there are more initiatives... or ideas of projects, which later have become separate organizations...', '... we have established the forum of parents...', by creating workplaces for themselves and others: '... I have never imagined that I will be a hired employee, by now I know that I will create workplaces for myself...'. The ability of organizations' development by the informants is disclosed by the activity of their established organizations ('... we have become one of the most known organizations...', '... in the fund field we are the largest according to turnovers...') and expansion ('...we have expanded to such solid organization...'). It is important to note that this ability is characteristic to all informants.

When analysing the informants' attitudes, it has become evident the attitude - social problems'solution is more important than personal welfare is characteristic for the second informant: '... if you more care of the solution of others' problems in your life.' And for the first informant: '... it seemed that we did not have anything, too much costs, money, but together with my husband we felt joy...', '... I felt communication joy, real self-dividing...'. The informants most thoroughly proved the attitude of a social entrepreneur that short joy in an achieved result sight to future - what else is it necessary to change?, which manifests through constant creation of new plans, is characteristic for him/her ('... while you are alive, you always have plans and projects...'), parallel performed activities ('... I always have parallel more or less projects...') and the search of new possibilities ('... there are a lot of areas where you should work...'). However, the research participants have not confirmed the attitude that work is the sense of life.

When analysing the explicit knowledge of the research participants, it has become evident that due to particularity of social activity policy and legislation knowledge is important for social entrepreneurs. The informants relate the knowledge to the understanding of education policy: '... I have begun to get deeper into education policy, educational goals, family priorities...', 'One of the main reasons that the educational goals do not coincide with curriculum....', '... inner sense that something is wrong with education...'. Thus it is possible to state that now this 
field of the policy is the most important for the informants. The way the informants acquire their knowledge is related to learning, continuous learning distinguished by the research participants proves that. Continuous learning, according to the informants, takes places at studies: '...$I$ have always studied...'; in the practical activity: '... practically learn from the life... ', '... by means of practical learning a person much more contacts...', 'In reality I might have finished my doctoral studies of life school...', 'This induced to get interested, take part in conferences...'. The informants point out that they learn very actively: ' ... you absorb the knowledge very actively; apply in the practice, demonstrate... ', '... I read a lot... ', '... and in the beginning we learnt, we took part in working groups, took part at a conference as speakers this helps to develop, invites elsewhere, you have to get ready...'. You learn from other people: '...nobody is higher and at the same time you are both a pupil and teacher..., ,, But those people also are teachers - they develop your tolerance, patience', '... we all need to learn new love talk with each other...' and from situations: „Learn from every situation.' According to the informants, learning has to last life-long: 'Whatever happens, you should not get asleep on what you know, you have to get deep.' Thus all informants have mentioned learning in one or other forms. Learning takes place both in practice and while studying.

When analysing the research data, the motives of the activity of social entrepreneurs - employees of the NGOs rendering social services have been distinguished. Altruism motivates the research participants to strive for society welfare. When analysing this motive, it is evident that it is disclosed through two aspects in the activity of the informants: the wish to help and the wish to sacrifice. The following statements reflect the with to help people: '... to help a person in any situation...', '... unbounded wish to help... ', '... your wish is to help namely in this field...'. The following phrases of the informants disclose the wish to sacrifice: '... to give yourself to others and certain financial resources, your energy, human resources...', '...also to give yourself to others, not only be happy with your life...', '... great treasure when you give yourself to others...', '... when you give something good, when you give yourself to others, it returns it returns by boomerang, really...'. Thus the research participants feel the wish to help people by solving their problems. They want to sacrifice their time, resources, energy because they see great good in this. When performing the research data analysis, creation of social value has been distinguished as one of the essential motives of a social entrepreneur. This motive is confirmed by three aspects: solution of society problems, impact on country's management as well as initiation of laws and their changes. The following statements of the research participants prove the solution of society problems: '... a properly brought up and educated child will later make harmonious families and will raise good Lithuanian citizens...', '... it is most effective to breed proper young generation...', 'But! Those 15 children have already changed. We have been able to retrieve 15 souls...', '...I think that our strongest idea to create conditions for establishing community schools...'. The statements confirming the impact upon country's management are as follows: '... that legal services for nongovernmental organizations would emerge at the municipality...', '... the same as with those 2 percent, sometimes one wants to say, ooo, I here brought those 2 percent to Lithuania... ', '... mainly we undertook acting in education field...'. The following phrases of the informants prove the initiation of laws and their changes: '... you initiate the laws' change in order that help would come only from organizations, it should emerge at state level...'. Thus it has become evident that creation of social value as motive is important for all research participants. They solve society problems by establishing new organizations, offering and implementing new ways of problem solution, influencing relevant fields of social life as well as initiating laws. Another important motive of a social entrepreneur working for a NGO is society progress. The informants understand it as person's progress ('... a person has to be supported not only financially, it is necessary that he / she would develop certain skills...'), country's progress ('... a properly brought up and educated child will later make harmonious families and will raise good Lithuanian citizens...', '...it is most effective to breed proper young generation...', '... it is most important if they have internal harmony, they search for something different, new...'). Thus it is possible to state that the research participants are motivated by the wish to contribute to creating both an individual and group and the country. All research participants named environment influence as important motive: this can be the influence of a family and acquaintances. The following statements prove this: ' ... my family, for example, has a tradition...', '... perhaps your family was such, your family circle turns more to that side...', '... and proper people approached me...', '... your acquaintances' circle pulled you to that side...', '... naturally my colleagues joined me...' . Thus the informants have been influenced by their family, acquaintances and colleagues when choosing the field of social activity.

The research has disclosed the following essential aspirations of a social entrepreneur: society welfare and the vision of the better world. The strive for society welfare manifests through the pursuit of separate society groups' welfare ('... the aim is one of the basic ones, it is that all our children were happy...'), through community changes ('... at school the aggression and offence has decreased, the school has started to take more responsibility...'), through the care of the people round about ('...it is important for me not only my life, but I care for what it is going on around me..., '... in order to stop untruth, to stop injustice, to intercede the weaker one, to direct own competences to help a crocked fallen person... ', '...it is desirable that everyone would feel well, that you would feel well; you know, try according to your possibilities to do it...'). All participants of the research have named the vision of the better world as strive. They informants realise it in their activity by doing good: '... everything started to increase, improve, get smart...', '... we do a lot of nice things, I think...', '... it would be good that everyone feels well, you know', as well as fighting with injustice: '... because I really stand against injustice, untruth...', '... I cannot see injustice...'. Thus the 
participants of the research not only do good transactions for the society but also they try preventing injustice.

\section{The profile of the social entrepreneurs working for non-governmental organizations}

Having performed the qualitative research and having disclosed the expression of the features of the social entrepreneurs chosen as informants working for the NGOs rendering social services similarities and differences of social entrepreneurs' activities have been revealed. Though the informants work for different organizations and perform more or less different activities, they need the same abilities and knowledge in initiating social changes and creating social value, they have characteristic corporate attitudes, features and objectives, the same motives induce their activity. The features of the informants disclosed during the research have coincided with the features of a social entrepreneur distinguished during the analysis of scientific literature and several new aspects have been revealed. Referring to these features, the model of the profile of social entrepreneurs working for non-governmental organizations has been constructed (Figure 2), the profile understood as the entirety of individual's typical features:

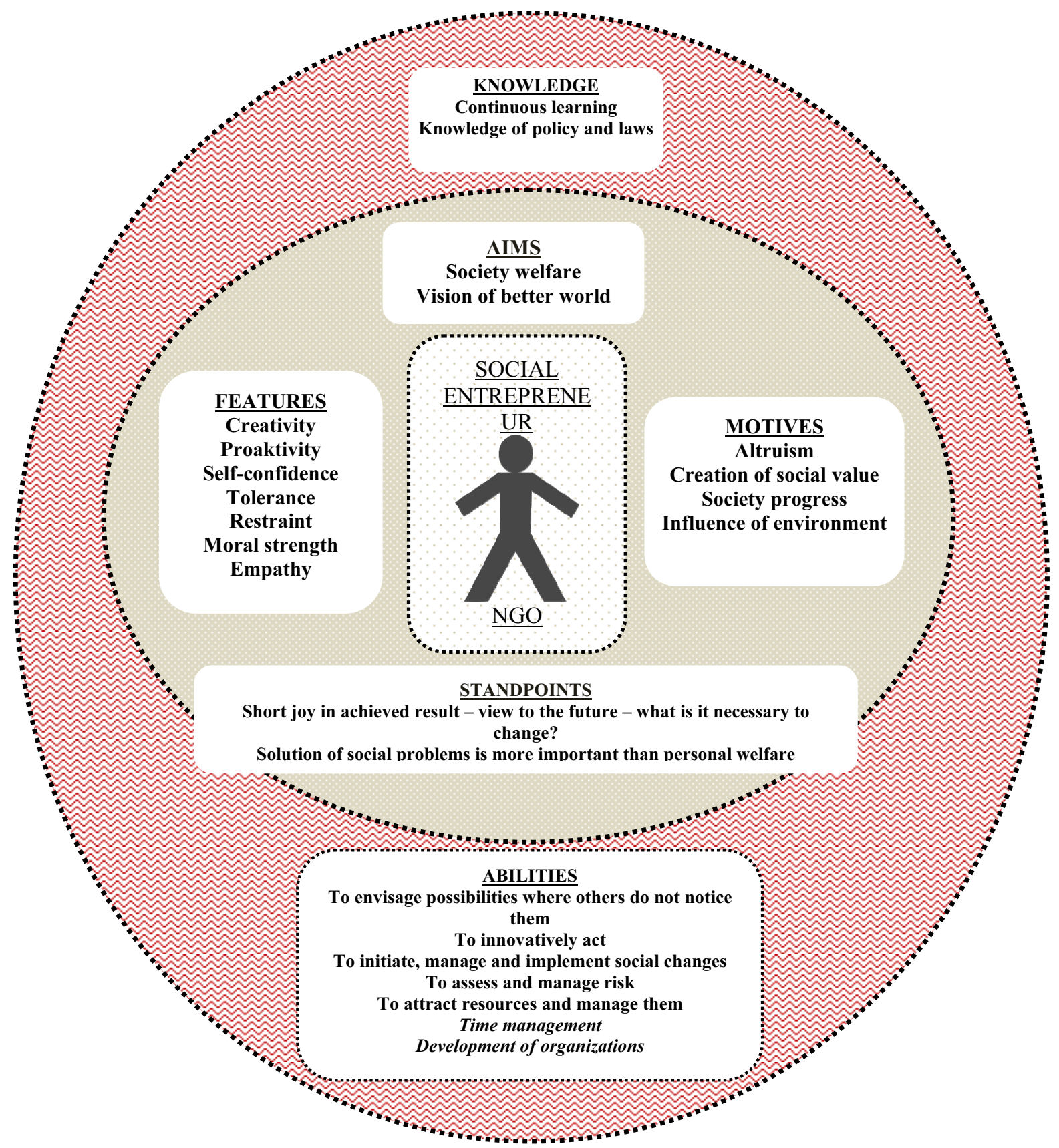

Figure 2. The model of the profile of the social entrepreneurs working for NGOs 
Thus the following features of the social entrepreneurs working for NGOs have become evident during the research: creativity, pro-activity, self confidence, tolerance, restraint, moral strength and empathy. The following features of the informants are expressed the most strongly: pro-activity and empathy. They have been highlighted by all participants of the research. Creativity and restraint are more characteristic for the second informant; the first participant of the research demonstrates the strongest selfconfidence and moral strength.

The abilities distinguished during the research are as follows: notice of possibilities, innovative activity, ability to initiate, manage and implement social changes, raise resources and handle them. However, the ability to manage risk is more expressed through the ability to take responsibility and to bravely take risky activities than through the ability to figure out and evaluate risk. All informants have highlighted the ability to innovatively act. The ability - to raise necessary resources - is the most strongly expressed by the social entrepreneurs who participated in the research; however, it is important that all three informants find the finances necessary for social initiatives by different ways. The abilities, which have been additionally revealed by the informants and which are not distinguished in scientific literature, are important for a social entrepreneur working for a NGO: time management and development of organizations. It is important to note that all participants of the research have initiated the establishment of successfully functioning NGOs rendering social services.

All participants of the research expressed their common viewpoint: short joy in an achieved result - sight to future - what else is it necessary to do? Also the informants have disclosed the priority of social problems' solution against personal welfare. Scientific literature stresses the viewpoint that the work of a social entrepreneur is the purport of life; it has not been characteristic for the research participants working for NGOs.

Referring to the results of the performed research the perception of policy and laws, and especially education policy, is the most important knowledge of the social entrepreneurs. The participants of the research have not disclosed more particular knowledge necessary for the social entrepreneurs working for NGOs. All informants have pointed out the importance of continuous learning by emphasizing practical learning.

The social entrepreneurs who took place in the research are motivated for their activity by altruism as well as the wish to pursue for society progress. The strongest motive of all informants is the wish to create social value; this exactly reflects the essence of social entrepreneurship. All participants of the research have indicated environment influence as important motive. The essential aspirations are as follows: society welfare and vision of the better world, which has been seen by all social entrepreneurs who participated in the research.

Thus having performed the research, it is possible to state that the features of a social entrepreneur distinguished in the theoretical part are characteristic for the social entrepreneurs working for non-governmental organizations and who took place in the research. Alongside the distinguished ones in scientific literature, the research disclosed additional abilities of time management and organization development. The informants have not confirmed only the viewpoint distinguished by scientists that the work for a social entrepreneur is the life essence all research participants stated that they easily coordinate their activities with their personal life. The three informants have expressed the particular profile of a social entrepreneur; only the first informant showed the exclusive self-confidence and moral strength, and the second one restraint and creativity.

\section{Conclusions}

- Social entrepreneurship is the process, during which a social entrepreneur creates a social value by pursuing social changes, by having recognized the possibility, which has not been noticed by the others, as well as, by properly evaluating and taking all possible risk and uniquely using possessed or borrowed resources. The essential difference between entrepreneurship and social entrepreneurship discloses in analysing their activity aims. The aim of social entrepreneurship is the creation of a social value, and an economic value becomes a spin-off that helps to implement ideas.

- The following essential features of a social entrepreneur are distinguished: creativity, productivity, self-confidence, tolerance, restraint, moral fibre and empathy; abilities - notice of possibilities, innovative activity, the ability to initiate, manage and implement social changes, attract resources and manage them, estimate and manage risk; knowledge - understanding of social problems, the knowledge of the risk, change and finance management, project activity, policy and legislation, continuous learning; viewpoints - the solution of social problems is more important than personal welfare, work is the purport of life, short joy in an achieved result - sight to future - what else it is necessary to do; motives - altruism, creation of a social value, society progress; ambitions - society welfare and vision of better world.

- The performed empiric research has shown that the abilities and features, which have been distinguished during the analysis of scientific literature, as well as additional abilities as time management and development of organizations are characteristic for the social entrepreneurs working for the NGOs rendering social services. The attitude that their work is their life meaning has not been characteristic for the informants; however, the research participants have confirmed all distinguished motives and aspirations by indicating the influence of the environment surrounding them upon their activity choice as motive. All informants have pointed out the importance of continuous learning and the knowledge of policy and legislation by not distinguishing the need for specific knowledge necessary for social activities. 
- Though the creation of social value is the activity oriented to public benefit by trying to resound society needs and problems, the research has disclosed that the social entrepreneurship of the interviewed NGO employees manifests not only in creating social value for the society by finding new and effective ways to solve social problems and initiating changes in laws of the country but also in taking care of the creation of social welfare for private persons.

- The constructed model of the profile of a social entrepreneur working for a NGO highlights the entirety of social entrepreneurs' features, which have been distinguished in scientific literature and confirmed in the research.

\section{References}

1. Auerswald, P. (2009). Creating Social Value. Stanford Social Innovation Review, Spring, 50-55.

2. Badelt, C. (1997). Entrepreneurshiptheoriesofthenon-profitsector. Voluntas, 8, (2), 162-178. http://dx.doi.org/10.1007/BF02354193

3. Bessant, J., \& Tidd, J. (2011). Innovation and Entrepreneurship. Chichester: Wiley.

4. Bygrave, W., \& Zacharakis, A. (2011). Entrepreneurship. Hoboken [N.J.]: JohnWiley.

5. Bornstein, D. (2007). How to Change the World. Social Entrepreneurs and the Power of New Ideas. Oxford University Press.

6. Bornstein, D., \& Davis, S. (2010). Social entrepreneurship: what everyone needs to know. Oxford: Oxford University Press.

7. Fillis, I., \& Rentschler, R. (2010). The role of creativity in entrepreneurship. Journal of Enterprising Culture, 18, (1), 49-81. http://dx.doi.org/10.1142/S0218495810000501

8. Gilmore, A., Gallagher, D., \& O'Dwyer, M. (2011). Is Social Entrepreneurship an Untapped Marketing Resource? A Commentary on its Potential for Small Sports Clubs. Journal of Small business and Entrepreneurship, 24, (1), 11-15.

9. Greblikaite,, J. (2011). Antrepreneriškumo raiškos raida ir šiuolaikiniai bruožai inovatyviose smulkiose ir vidutinèse ịmonèse (Daktaro disertacija, Mykolo Romerio universitetas, 2011).

10. Groenewald, T. (2004). A Phenomenological Research Design Illustrated. International Journal of Qualitative Methods, 3, (1).

11. Hemingway, C.A. (2005). Personal Valuesas A Catalist for Corporate Social Entrepreneurship. Journal of Business Ethics, 60, 233-249. http://dx.doi.org/10.1007/s10551-005-0132-5

12. Hisrich, R.D., Peters, M.P., \& Shepherd, D.A. (2010). Entrepreneurship. NY: McGraw-Hill//rwin.

13. Jucevičius, R. (1998). Strateginis organizaciju vystymas. Kaunas: Pasaulio lietuvių kultūros, mokslo ir švietimo centras.

14. Kaplan, J.M., \& Warren, A.C. (2007). Patterns of Entrepreneurship. Hoboken [N.J.]: Wiley.

15. Kuvykaite, R., ir Alimienè, M., (2006). Antreprenerystès ịtaka mažų ir vidutinių imonių internacionalizacijai. Organizaciju vadyba, 39, 7-20.

16. Light, P.C. (2009). Social Entrepreneurship Revisited. Stanford Social Innovation Review, Summer, 21-23.

17. Mair, J., \& Marti, I. (2006). Social entrepreneurship reseach: A source of explanation, prediction, anddelight. Journal of World Business, 41, 36-44. http://dx.doi.org/10.1016/j.jwb.2005.09.002

18. Noruzi, M.R., Westover, J.H., \& Rahimi, G.R. (2010). An Exploration of Social Entrepreneurship in the Entrepreneuship Era. Asian Social Science, 6, (6), 3-10.

19. Pagirys, J. (2009). Inovacijos: mokslas rinkoje. Nesèkmingu Europos bandymų pavyti JAV priežastys. Postscriptum, 16.

20. Peredo, A.M., \& McLean, M. (2006). Social entrepreneurship: A critical review of the concept. Journal of World Business, 41, 5665. http://dx.doi.org/10.1016/j.jwb.2005.10.007

21. Petuškiené, E., \& Glinskienè, R. (2011). Entrepreneurship as the Basic Element for the Successful Employment of Benchmarking and Business Innovations. Inžinerinè ekonomika EngineeringEconomics, 22, (1), 69-77.
22. Phills, J.A. Jr., Deiglmeier, K, \& Miller, D.T. (2008). Rediscovering Social Innovation. Stanford Social Innovation Review, Fall, 34-43.

23. Scarborough, N.M. (2011). Essentials of Entrepreneurship and Small Business Management. Upper Saddle River [N.J.]: PrenticeHall.

24. Shaw, E., \& Carter, S. (2007). Social Entrepreneurship. Teoretical antecedents and empirical analysis of entrepreneurial processes and outcomes. Journal of Small Business and Enterprise Development, 3, (14), 418-434. http://dx.doi.org/10.1108/14626000710773529

25. Snitka, V., ir Gerdvila, S. (2001). Antrepreneryste ir jos ịtaka ekonomikos augimui. Ekonomika, 54, 126-134.

26. Stripeikis, O. (2008). Antrepreneriškumo formavimas Lietuvos smulkaus ir vidutinio verslo įmonėse. Vadybos mokslas ir studijos - kaimo verslu ir ju infrastruktūros plètrai, 15, (4), 1-11.

27. Thompson, J.L. (2002). The world of social entrepreneur. The International Journal of Public Sector Management, 5, (15), 412431. http://dx.doi.org/10.1108/09513550210435746

28. Weerawardena, J., \& Mort, G.S. (2006). Investigating social entrepreneuship: A multidimensional model. Journal of World Business, 41, 21-35. http://dx.doi.org/10.1016/j.jwb.2005.09.001

29. Williams, D.A., \& K'nIfe, K.A.K. (2011). The dark side of social entrepreneurship. Proceedings of the Academy of Entrepreneurship, 17, (1), 67-72.

30. Židonis, Ž. (2008). Verslumo skatinimo politika Lietuvoje: produktyvi, neproduktyvi ir destruktyvi antrepreneryste. Viešoji politika ir administravimas, 26, 9-16.

\section{E. Adomavičiūtė, B. Janiūnaitè, E. Štuopytė}

\section{Nevyriausybinėse organizacijose dirbančių socialinių antrepreneriu} profilis

\section{Santrauka}

Nuolatiniai pokyčiai, originalūs sprendimai, inovaciju kūrimas turi tapti bet kurios organizacijos veiklos pagrindu (Petuškienè, Glinskienè, 2011). Inovacijos nèra vien techninis ar technologinis, bet ir kompleksiškas socialinis procesas, kuriame svarbų vaidmenį vaidina „minkštieji“ veiksniai, iš kurių svarbiausias - žmogiškasis potencialas: kūrybiškumas, novatoriškumas, antrepreneriškumas. Šiame straipsnyje koncentruojamasi ị antrepreneriškumo reiškinị.

Antrepreneris yra nauju galimybiu ieškotojas ir ju igyvendintojas, o galimybès slypi ne tik versle, kur svarbiausia siekti pelno, bet ir viešajame sektoriuje, kur antrepreneriai sprendžia socialines problemas (Židonis, 2008). Siekiant teigiamų ilgalaikių pokyčių, reikalingi žmonès, kurie supranta pamatines problemas ir turi aiškią viziją, kaip jas spręsti, kurie turi talenta suburti komanda ir drąsos eksperimentuoti bei kuriems labiau rūpi socialiniu problemų sprendimas nei asmeninè nauda (Bornstein, Davis, 2010). Didejantis supratimas, kad socialiniu problemu mastas visame pasaulyje yra milžiniškas ir jos nebegali būti išspręstos vien tradicinèmis priemonemis, skatina naujų galimybių paieškas, kurių imasi socialiniai antrepreneriai. Jie siekia dirbti visuomenès labui, spręsdami socialines problemas netradiciniais, kūrybiškais, inovatyviais, ilgalaikiais bei efektyviais būdais. Socialiniai antrepreneriai įžvelgia galimybes ten, kur kiti jų nepastebi ir igyvendina sumanytas idèjas nepaisydami jokių kliūčių.

Socialiniu tikslu siekimas yra pagrindinis socialinès antreprenerystès išskirtinumas (Peredo, McLean, 2006). Socialiniai antrepreneriai veikia išskirtinai visuomenès labui (Thompson, 2002). Pasak Drayton (2011), socialiné antreprenerystė yra didelių socialinių pokyčių pasaulyje pagrindas. Socialiniai antrepreneriai ne tik suvokia ir konstruoja naujus socialiniu problemu sprendimo modelius, bet savo idejjomis užkrečia kitus bei igalina juos veikti visuomenès labui. Kaip teigia Borstein (2007), socialiniai antrepreneriai paankstina sisteminius pokyčius visuomenèje: jie keičia žmonių elgesio modelius ir suvokimą.

I socialinès antreprenerystès reiškinị gilinasi ịvairūs mokslininkai: Bornstein (2007), Bornstein, Davis (2010), Gilmore, Gallagher, O’Dwyer (2011), Light (2009), Mair, Marti (2006), Noruzi, Westover, Rahimi (2010), Peredo, McLean (2006), Thompson (2002), Weerawardena, Mort (2006), Williams, K'nIfe (2011). Socialinę antreprenerystę kaip procesą tyrinejja: Bessant, Tidd, (2011), Shaw, Carter (2007). Socialinių antrepreneriu bendradarbiavimą analizuoja Drayton (2011). Socialinę antreprenerystę nevyriausybinèse organizacijose tyrè Badelt (1997), tačiau neaptikta tyrimų, analizuojančių socialinių antrepreneriu charakteristikas, tik Hemingway (2005) tyrimas išryškino socialinių 
antreprenerių vertybes. Fillis, Rentschler (2010) gilinosi ị kūrybiškumo svarbą antrepreneriškoje veikloje.

Nors antreprenerystès ir socialinès antreprenerystès fenomenas sulaukia nemažai mokslininkų dèmesio, tačiau kol kas nepakankamai tyrimų koncentruojasi ị nevyriausybinèse organizacijose (toliau - NVO) dirbančius socialinius antreprenerius. Kodèl svarbu tyrinèti būtent NVO veikiančius socialinius antreprenerius?

Didžiają daugumą savo veiklų socialiniai antrepreneriai vykdo būtent nevyriausybinèse organizacijose (Bygrave, Zacharakis, 2011). Pasak Badelt (1997), antrepreneriai dažnai ikuria naujas NVO ir jose koncentruojasi i socialinius pokyčius: naujų visuomenès poreikių identifikavimą bei naujų paslaugų teikimą, taip pat i organizacijos galimybes pasiūlyti naują (geresnę) teikiamų paslaugų kokybę. Socialinès antreprenerystės tikslas nevyriausybinèse organizacijose yra kurti novatoriškus, geresnius už prieš tai buvusius, socialinių problemu sprendimus (Gilmore, Gallagher, O’Dwyer, 2011), kitaip sakant, kurti socialine verte. Pasak Weerawardena ir Mort (2006), būtent socialinè antreprenerystė sudaro sąlygas NVO ne tik igyvendinti savo socialinę misiją, bet ir pasiekti ilgalaikiu tikslų. Kita vertus, NVO dirbant savanoriams, didesne dalis iniciatyvu yra sẻkminga todèl, kad savanoriai dažnai yra „,arčiau“ tikrujų žmonių poreikių, juos sugeba išgirsti ir suvokti (Thompson, 2002). Asmeniškai suvokdami socialinès problemos esmę bei jos sprendimo spragas, jie arba patys imasi iniciatyvos jas spręsti, arba pasiūlo nauju idejų organizacijos vadovams. Taigi socialinès antreprenerystès fenomenas pirmiausia domina mokslininkus dèl šių probleminiu klausimų: kokiomis charakteristikomis pasižymi nevyriausybinèse organizacijose veikiantis socialinis antrepreneris? Koks profilis būdingas nevyriausybinèse organizacijose veikiančiam socialiniam antrepreneriui?

Pirmoje straipsnio dalyje atskleidžiamas antreprenerystės ir socialinès antreprenerystès sampratụ santykis. Antroje dalyje išskiriamos socialinio antreprenerio, dirbančio NVO, charakteristikos. Trečioje dalyje pagrindžiama atlikto empirinio tyrimo metodologija. Ketvirtojoje straipsnio dalyje, remiantis atlikto tyrimo duomenimis, atskleidžiama NVO darbuotojų socialinės antreprenerystès charakteristikų raiška, o penktoje dalyje pateikiamas nevyriausybinèse organizacijose dirbančiu socialinių antrepreneriu profilio modelis.

Straipsnyje daromos šios esminès išvados:

- Socialiné antreprenerysté yra procesas, kurio metu socialinis antrepreneris, siekdamas socialinių pokyčių, atpažinęs galimybę, kurios nepastebejo kiti, tinkamai ịvertindamas bei prisiimdamas visą galimą riziką ir unikaliai panaudodamas turimus ar pasiskolintus išteklius, sukuria socialinę vertę. Esminis skirtumas tarp antreprenerystès ir socialinès antreprenerystès išryškèja analizuojant veiklos tikslus: socialinès antreprenerystès tikslas yra socialinès vertès kūrimas, o ekonominè vertè tampa šalutiniu produktu, padedančiu ịgyvendinti idejjas.

- Vertinant socialinių antrepreneriu, dirbančiu NVO veiklos specifiką, mokslinès literatūros analizès metu išskirtos šios esminès charakteristikos: bruožai - kūrybiškumas, proaktyvumas, pasitikèjimas savimi, tolerancija, santūrumas, moralinis tvirtumas ir empatija; gebejjimai - galimybių pastebẻjimas, inovatyvi veikla, gebejimas inicijuoti, valdyti ir igyvendinti socialinius pokyčius, pritraukti išteklius bei juos valdyti, apskaičiuoti ir valdyti riziką; žinios - socialiniu problemų suvokimas, rizikos, pokyčių ir finansų valdymo, projektinès veiklos, politikos ir istatymu žinios, nuolatinis mokymasis; požiūriai - socialiniu problemu sprendimas svarbesnis nei asmeninè gerovè, darbas gyvenimo prasmè, trumpas džiaugsmas pasiektu rezultatu - žvilgsnis i ateiti - ka dar reikia pakeisti?; motyvai - altruizmas, socialinès vertès kūrimas, visuomenès progresas; vertybès - visuomenès gerovė bei geresnio pasaulio vizija.

- Atliktas empirinis tyrimas parodè, jog socialines paslaugas teikiančiose NVO dirbantiems socialiniams antrepreneriams yra būdingi visi mokslinès literatūros analizès metu išskirti bruožai ir gebëjimai, taip pat tokie papildomi gebejjimai kaip laiko vadyba ir organizacijų vystymas. Informantams nebuvo būdingas požiūris, jog darbas yra gyvenimo prasmé, tačiau tyrimo dalyviai patvirtino visus išskirtus motyvus ir vertybes, kaip papildomą motyvą nurodydami juos supančios aplinkos ịtaką veiklos pasirinkimui. Visi informantai akcentavo nuolatinio mokymosi svarbą bei politikos ir ịstatymų žinias, neišskirdami socialinėms veikloms vykdyti reikalingų specifinių žinių poreikio.

- $\quad$ Nors socialinès vertès kūrimas yra veikla orientuota ị visuomeninę naudą, stengiantis atliepti visuomenès poreikius ir problemas, tyrimas atskleidè, jog apklaustu NVO darbuotoju socialinè antreprenerystė pasireiškia ne tik kuriant socialinę vertę visuomenei, atrandant naujus ir efektyvius būdus socialinèms problemoms spręsti bei inicijuojant pokyčius šalies įstatymuose, bet ir rūpinantis privačių asmenų socialinès gerovès kūrimu.

- Sudarytas NVO dirbančiu socialiniu antrepreneriu profilio modelis, kuriame pateikiamos esminès tyrimo metu atskleistos charakteristikos, kurių identifikavimas ir ugdymas leidžia vystyti socialinès antreprenerystès kompetencijas organizacijose bei tobulinti tokio pobūdžio specialistus rengiančiu institucijų studijụ programas.

Reikšminiai žodžiai: antreprenerystè, socialinè antreprenerystè, nevyriausybinès organizacijos, socialinė verte.

First received: August, 2012

Accepted for publication: September, 2012 